\title{
Computer Aided Drawing Programs in Interior Architecture Education
}

\author{
İç Mimarlık Eğitimi İçerisindeki Bilgisayar Destekli Çizim Programları
}

Received: March 4, 2021
Accepted: April 15, 2021

\begin{abstract}
Interior architecture education has displayed much variability from the past to the present day. Additionally, computer-aided drawing systems have become an irreplaceable part of interior architecture education, as in all other design disciplines. The contribution of computers in education to the design process has created a process of, Hand drawing - Design - Design in computer environment - Product - Prototype. Currently, traditional drawing methods are used much less. Computer-aided drawing programs in universities display differences in terms of models and content. Additionally, the year and semester in which these lessons are taught are different in every university. In this context, this study deals with computer-aided drawing lessons in a total of 63 programs in 31 interior architecture departments and 32 interior architecture and environmental design departments in Turkey and the Turkish Republic of Northern Cyprus linked to the Council of Higher Education (YÖK) currently. This research was completed with the screening model. Data collection started in October 2020 and was completed at the end of 15 days. Screening was performed to learn which programs are taught in the programs in interior architecture and interior architecture and environmental design departments in different faculties. The software features of these programs were analyzed. The results of the study revealed the similarities of the different programs to each other.
\end{abstract}

Key Words: Computer Aided drawing, Interior architecture education, Software in Interior Architecture, Software features.

\section{Özet}

İç Mimarlık eğitimi geçmişten günümüze çok değişkenlik göstermiştir. Eğitimin ilk yıllarında el çizimiyle yapılan tasarımlar ve sunumlar günümüzde yerini bilgisayar programlarıyla yapılan çizim ve sunumlara bırakmıştır. Bununla birlikte, bilgisayar destekli çizim sistemleri, tüm tasarım disiplinlerinde olduğu gibi iç mimarlık eğitiminin de vazgeçilmez bir parçası olmuştur. Bilgisayarın eğitimdeki tasarım sürecine katılmasıyla birlikte önümüze çıkan süreç

El çizimi -Tasarım - Bilgisayar Ortamında Tasarım - Ürün- Ürün Temsili

Günümüzde geleneksel çizim yöntemleri çok daha az kullanılmaktadır. Üniversitelerde bilgisayar destekli çizim programlarının modeli ve içeriği farklılık göstermektedir. Ayrıca her üniversitede bu derslerin öğretildiği yıl ve eğitim yarıyılı farklıdır. Bu bağlamda, bu çalışmada günümüzde YÖK'e bağlı Türkiye ve KKTC toplamında otuzbir iç mimarlık bölümü ile otuziki iç mimarlık ve çevre tasarımı bölümünde olmak üzere toplam 63 programda, bilgisayar destekli çizim derslerinde öğretilen yazılımlar ele alınmıştır.

$\mathrm{Bu}$ araştırma tarama modeliyle gerçekleştirilmiştir. Verilerin toplanmasina Ekim 2020 tarihinde başlanıp 15 sonunda tamamlanmıştır. Farklı fakülteler altında olan, iç mimarlık ile iç mimarlık ve çevre tasarımı bölümleri ders programlarının içerisinde hangi programlar öğretildiği taranmıştır. Bu programlarım yazılım özellikleri analiz edilmiştir. Çalışma sonucunda farklı programların birbirine benzerlikleri olduğu ortaya çıkarılmıştır.

Anahtar Kelimeler: Bilgisayar destekli çizim, İç Mimarlık Eğitimi, bilgisayar destekli çizim, İç Mimarlıktaki Yazılımlar, Yazılım Özellikleri.

\footnotetext{
${ }^{7}$ Assist. Prof. Dr. Near East University, Faculty of Architecture, Department of Interior Architecture, Cyprus.

${ }^{8}$ Interior. Arch. MA. Near East University, Faculty of Architecture, Department of Interior Architecture, Cyprus.
} 


\section{Introduction}

The computer-aided drawing programs taught during the interior architecture educational process display variations according to organization.

"The best approach is to determine and use the tools required for each stage of a job."

There are no rules related to which of these tools may be used in which stages (Howard, 1993; Ketizmen, 2002). The only way for a designer to show their thoughts is through the use of drawing tools. In this context, with changing technologies, research into which drawing tools and computer programs are taught during interior architecture education carries great importance.

A person learns to handle a pencil as a child. Real training only comes much later. Drawing is not considered an important subject at secondary school diploma level by any means. A university level architecture curriculum generally includes classical lectures such as drawing and painting, although computer-aided representation methods were gradually included as the course plans were reformed (Martens \& Peter, 2004).

Since 1982, computer-aided design (CAD) technologies have changed the way the world works in the field of architecture. This has replaced the traditional drafting and design methods, allowing the industries to plan, simulate and produce new ideas in a single program. CAD made it possible to view different aspects and perspectives of building forms within a single program and allowed designers to locate and fix problems quickly and efficiently (Onur \& Nouban, 2019).

While the use of traditional and computer-aided drawing devices continues together in interior architecture education, computer-aided drawing programs are an irreplaceable part of interior architecture education, as in all design disciplines.

The language architects use to express information about a building is drawings. Until the 1960s, they were done by pencil and ink, then in the 1960s CAD became a new tool for these drawings. By means of CAD, drafters had an opportunity to visualize the drawings in a digital environment. From that moment on, drawings were produced more quickly, changes could be made faster and computers became an integral part of architecture offices. When CAD developed in $3 \mathrm{D}$, it made it possible to obtain even more realistic visual documents (Scheer, 2014).

Though different computer-aided drawing programs are taught in universities, their presence in undergraduate education is inevitable.

In this context, this study researched the programs used in computer-aided drawing lessons in a total of 63 programs, 31 in interior architecture departments and 32 in interior architecture and environmental design departments, in Turkey and the Turkish Republic of Northern Cyprus, hereinafter called (TRNC) linked to the Council of Higher Education (YÖK) at present.

This study reveals the history of interior architecture education, programs taught during interior architecture education and the software features of these programs.

In the same way, the general aim of the study was to determine the content and software features of computer-aided drawing programs taught during education in all interior architecture and interior architecture and environmental design departments linked to YÖK.

In line with this aim, answers to the following questions were sought;

What computer-aided drawing programs are taught during the interior architecture educational process in Turkey and the TRNC?

What are the software features of the computeraided drawing programs?

What are the similarities and differences between the computer-aided drawing programs that are taught?

\section{Material and Method}

Material for the study comprised the computeraided drawing programs and software features of these programs taught in a total of 63 interior architecture and interior architecture and environmental design departments located in Turkey and TRNC. This research was completed with the screening method. The collection of data started in October 2020 and was completed at the end of 15 days. There are 32 interior architecture and environment design departments and 26 interior architecture departments providing education in Turkey. There are 5 
interior architecture departments linked to YÖK located in TRNC.

The available curricula were reached though the university websites and the content of computeraided drawing lessons within the curriculum were reached and data about the programs taught were listed using a table. For departments where data could not be reached through the website, attempts were made to reach heads of department by email.

As there are two different departments registered with YÖK, the data were analyzed in 2 separate tables for interior architecture and environmental design departments and interior architecture departments. The study evaluated data in each table separately and then assessed the software features of the programs in the tables.

After performing a literature study related to the topic, the names of computer lessons taught in interior architecture departments in universities were determined as a result of screening performed within the scope of the study and each program was separately screened and software features were revealed. All data were tried to be accessed over the internet. For the information that could not be reached, the information was obtained by sending an e-mail to the relevant universities. The obtained data were transferred to an Exel table and converted into a table format.

\section{Historical Background of Interior Architecture Education}

The oldest interior architecture education began with Parsons design school founded in 1896. The first interior architecture department was created in 1906 by Frank Alvah Parsons in the United States of America (The New School, 2019).

The first architecture education in Turkey began with Painting and Sculpture education of twentyone students by an eight-person teaching staff on 2 March 1883 in the Sanayi-Nefise Mektebi (School of Arts-Fine), currently Mimar Sinan Fine Arts University (MSFAU), in the building opposite the Archeology Museum. However, before this, the syllabus in Mühendishane-i Berri Hümayun (Imperial School of Naval Engineering), currently Istanbul Technical University (ITU), included lessons in the field of architecture and began to provide architecture information according to western rules. In 1883, the Mühendishane-i Berr-i Hümayun transformed to Hendese-i Mülkiye (Geometry of Property) and in 1909 took the name Mühendis Mekteb-i Alisi (School of Engineering) and provided education to cultivate civil architects and engineers. In 1928, the name of the SanayiNefise Mektebi was changed to the Fine Arts Academy. From 1929-1932, interior architecture was first founded as a branch within the Department of Decoration. In this way, the interior architecture specialist area was included within different topics in the architecture specialist field.

\section{Drawing Tools used in Interior Architecture Education}

A variety of graphics and drawings are used in interior architecture applications. Drawings are divided into sections as concept drawings, sketches, rough plan drawings, applied drawings, detail drawings and perspectives. Materials include unlimited drawing tools and equipment for a variety of drawing types. These tools comprise compasses, rulers, T-squares, a variety of drafts, straight and circular templates, set squares, sketch paper, snake ruler, rolls of copy paper, presentation paper, curved rulers, erasers, paper bands, paste erasers, utility knife, technical pens, pencils and paper cleaning brushes (Bardak, 2007). Very great care and manual skills are required in order to use all this equipment. Even the smallest errors on drawings can lead to the designer having to completely redraw the drawing. This situation leads the designer to spend more time than necessary on sketches (Mitton, 2003).

In recent times, many schools and companies have completed the majority of drawings in the digital environment using computer-aided drawing tools. After the use of computer-aided drawing tools began, designers began to forget all the equipment they had previously used for drawing (Bardak, 2007).

"Today, computers are used to produce, store, revise and send original drawings. The process of producing drawings with this method is named computer-aided drawing or computer-aided design and drawing. This and similar terms may be used in place of the other" (Aydın, 2004).

First Use of Computer-Aided Drawing Tools in Architecture Education in Turkey.

MSFAU Faculty of Architecture organized a laboratory to teach computer-aided drawing in March of 1991. The laboratory was placed in a previous design studio. Though initially without ostentation, the founders maintained their focus on achieving high targets. At this point, many Turkish architects began to work with computer- 
aided drawing systems. As a result, computeraided drawing became an irreplaceable case and architects began to look for graduates who were able to use computer-aided drawing programs. Additionally, students wanted to resolve any deficiencies related to computers immediately. Hence, computer laboratories began to provide significant contributions to architecture and interior architecture students. One of the targets in 1993 was to organize a research center. This research center would focus on development of design research, coordination with other research traditions, and sharing of experiences and new technological advantages.

In the 1990s the quality of software and equipment tools increased and the use of design implementations in the computer environment increased in universities. This development, apart from affecting the design method, ensured the best design was achieved with data collection in the design. Drawing applications in computer environments were first included in master's education and then in undergraduate educational programs.

In 1992, the main computer equipment in the computer-aided drawing laboratory in the university were: 11 PCs with color screens, mouse and keyboard, 2 dot-matrix printers, 2 plotters, 1 LaserJet printer, and 1 scanner. The main software included disk operation system (DOS) AutoCAD, Norton, Autoshell, Wordstar, Lotus 123, and Vertura Desktop. The computeraided drawing course could be given to at most 30 students in each semester and was offered in the 3rd and 4th semesters. This course generally included the main software and operating systems. Each student had to present a simple project at the end of each semester (Ataç, 1992).

Computer-aided drawing in interior architecture education dates back about 20-25 years. At present, all universities offering interior architecture education provide computer-aided drawing education.

"In Turkey, after IBM Limited Company donated a significant number of computer-aided design systems to ITU Faculty of Architecture in 1987, computer-aided design education began in architecture" (Eczacıbaşı, 1997).

According to screening in November 2019, apart from one university, all universities providing interior architecture and interior architecture and environmental design education in Turkey and
TRNC linked to YÖK provide education about the use of computer-aided drawing tools.

Contribution of Computer-Aided Drawing Lessons to Interior Architecture Education

One of the areas where students beginning interior architecture education experience difficulties is gaining the ability to think in 3 dimensions. Attempts are made to explain and teach this to students by constructing a variety of models and with 3-dimensional hand drawings. This is so that in future classes, students will be stronger and quicker in transferring the ideas in their minds to a computer with 3-dimensional perception of interior space designs.

Computer-aided drawing tools, which provide designers with some convenience not offered by traditional drawing tools, play an important role within the interior space design process to a considerable degree. No matter how important the use of drawing tools in the interior design process, they carry just as much importance within interior architecture education (Denerel \& Birişçi, 2019).

Processes performed by computers in the area of interior architecture are completed in three different ways.

Transfer of hand-drawn products into the computer environment.

\section{Drawing a Designed Project}

Beginning a design directly by drawing in the computer environment (Bardak, 2007).

In terms of the design process, though the 2dimensional structure of the computer screen involves similar problems to the drawing table, apart from shortening the drawing process, the contribution in terms of visualizing a building in 3-dimensions is indisputable (Utkutuğ, 2000).

The visualizing of a space in 3-dimensions benefiting from virtual reality technologies eases perception and is enriched by the possibility of moving within or around the design and correcting design errors. Building simulation programs provide great benefit in terms of analyzing the performance of a building and bringing all aspects including materials, energy and costs to optimum levels. The information produced during the design stage with a computer offers the opportunity to complete the production, installation, renovation, 
maintenance-repair and even demolishing stages rapidly without mistakes, speeds up all processes and allows high rates of automation (Utkutuğ, 2000; Denerel, 2011). Computers are currently a necessary tool for all designers. The electronic drawing pages offered by softwares provide great convenience for designers in coloring, image processing and color differentiation. Twodimensional drawing software and modeling software have transformed from being something desired to being a necessary assistant (Baker, 1993).

\section{Advantages of the Use of Computers}

The advantages offered by the use of computers for designers may be explained as follows: drawing quality, easy material assignment, threedimensional drawing and expression, ease of copying, meet now, ease of transition in scale, easy accessibility of prepared forms, gaining time, easy communication on the internet, ease of use of archives, photo-realistic rendering, easy revision of mistakes, increased flexibility for the designer, ability to move around within the virtual space and offering color choices (Bardak, 2007).

\section{Research findings}

Data collection started in October 2020 and was completed at the end of 15 days. In the study, the educational curricula in 63 universities were screened. This screening was completed by accessing the university websites or by emailing the heads of department. Information accessed and obtained by email were assumed to be accurate and this part of the study ended. During screening, no information could be reached for 3 universities. The screening examined computeraided drawing lessons and accessed 60 educational curricula from a total of 83 interior architecture and interior architecture and environmental design departments. During screening, the features and aims of use for computer-aided drawing programs taught in the departments were determined and investigated in detail. Apart from 1 university, it was found that computer-aided drawing lessons were part of the mandatory courses among the curricula accessed for all departments.

Table 1 shows the lesson distribution according to a total of 8 semesters in interior architecture and interior architecture and environmental design departments. The most intense semester in interior architecture departments is the 3rd semester at $34.82 \%$. With very little difference, this is followed by the 4 th semester at $28.78 \%$. After this comes the 2nd semester at $15.15 \%$, the 5 th semester at $10.60 \%$, the 1 st semester at $6.06 \%$, and the 7 th and 8 th semesters at $1.51 \%$. The lesson distribution for a total of 8 semesters in the interior architecture and environmental design departments is shown. In the interior architecture and environmental design departments, the most intense semester is the 3rd semester at $31.32 \%$. With very little difference, this is followed by the 4 th semester at $28.91 \%$. After this comes the 5 th semester at $14.45 \%$, the 2nd semester at $10.84 \%$, the 6 th semester at $6 \%$, the 1 st semester at $4.81 \%$, the 7 th semester at $2.40 \%$ and finally the 8 th semester at $1.20 \%$.

Table 1.

Class distribution according to semester for Interior Architecture and Interior Architecture and Environmental Design Departments.

\begin{tabular}{|c|c|c|c|c|c|c|c|}
\hline \multicolumn{8}{|c|}{ INTERIOR ARCHITECTURE DEPARTMENT } \\
\hline \multicolumn{8}{|c|}{ 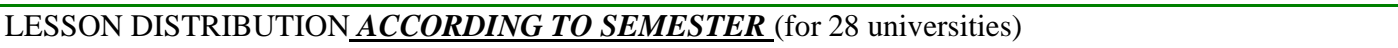 } \\
\hline \multicolumn{8}{|c|}{ TOTAL 66 classes } \\
\hline \multicolumn{8}{|c|}{ SEMESTER } \\
\hline 1 & 2 & 3 & 4 & 5 & 6 & 7 & 8 \\
\hline 4 classes & 10 classes & 23 classes & 19 classes & 7 classes & 1 class & 1 class & 1 class \\
\hline $6.06 \%$ & $15.15 \%$ & $34.82 \%$ & $28.78 \%$ & $10.60 \%$ & $1.51 \%$ & $1.51 \%$ & $1.51 \%$ \\
\hline \multicolumn{8}{|c|}{ INTERIOR ARCHITECTURE AND ENVIRONMENTAL DESIGN DEPARTMENT } \\
\hline \multicolumn{8}{|c|}{$\begin{array}{l}\text { LESSON DISTRIBUTION } \underline{A C C O R D I N G} \text { TO SEMESTER } \\
\text { TOTAL } 83 \text { CLASSES (according to } 31 \text { universities) }\end{array}$} \\
\hline \multicolumn{8}{|c|}{ SEMESTER } \\
\hline 1 & 2 & 3 & 4 & 5 & 6 & 7 & 8 \\
\hline 4 classes & 9 classes & 26 classes & 24 classes & 12 classes & 5 classes & 2 classes & 1class \\
\hline $4.81 \%$ & $10.84 \%$ & $31.32 \%$ & $28.91 \%$ & $14.45 \%$ & $6 \%$ & $2.40 \%$ & $1.20 \%$ \\
\hline
\end{tabular}


Table 2 includes the lessons found on the curricula for both departments. Interior architecture and environmental departments teach a total of 10 different computer programs. These are AutoCAD, 3ds-Max, V-Ray, Sketchup, Photoshop, Corel Draw, Rhino, Revit, Lumion, and Twinmotion programs. In interior architecture departments, a total of 13 different programs are taught. These are AutoCAD, 3ds-
Max, V-Ray, Sketchup, Photoshop, Corel Draw, Rhino, Grasshopper, Lumion, Archicad, Adobe Illustrator, Mentalray and Radiosity programs.

For all universities screened, it appeared that the AutoCAD program was included in the mandatory lessons on the curriculum in both departments. The other programs differed according to department.

Table 2.

Computer classes given in interior architecture and interior architecture and environmental design departments.

\begin{tabular}{|c|c|}
\hline \multirow{11}{*}{ 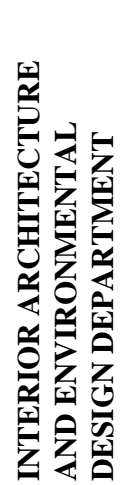 } & PROGRAM NAMES \\
\hline & AUTOCAD \\
\hline & 3DS-MAX \\
\hline & V-RAY \\
\hline & SKETCHUP \\
\hline & PHOTOSHOP \\
\hline & COREL DRAW \\
\hline & RHINO \\
\hline & REVIT* \\
\hline & LUMION \\
\hline & TWINMOTİON* \\
\hline TOTAL 10 & DIFFERENT PROGRAMS \\
\hline
\end{tabular}

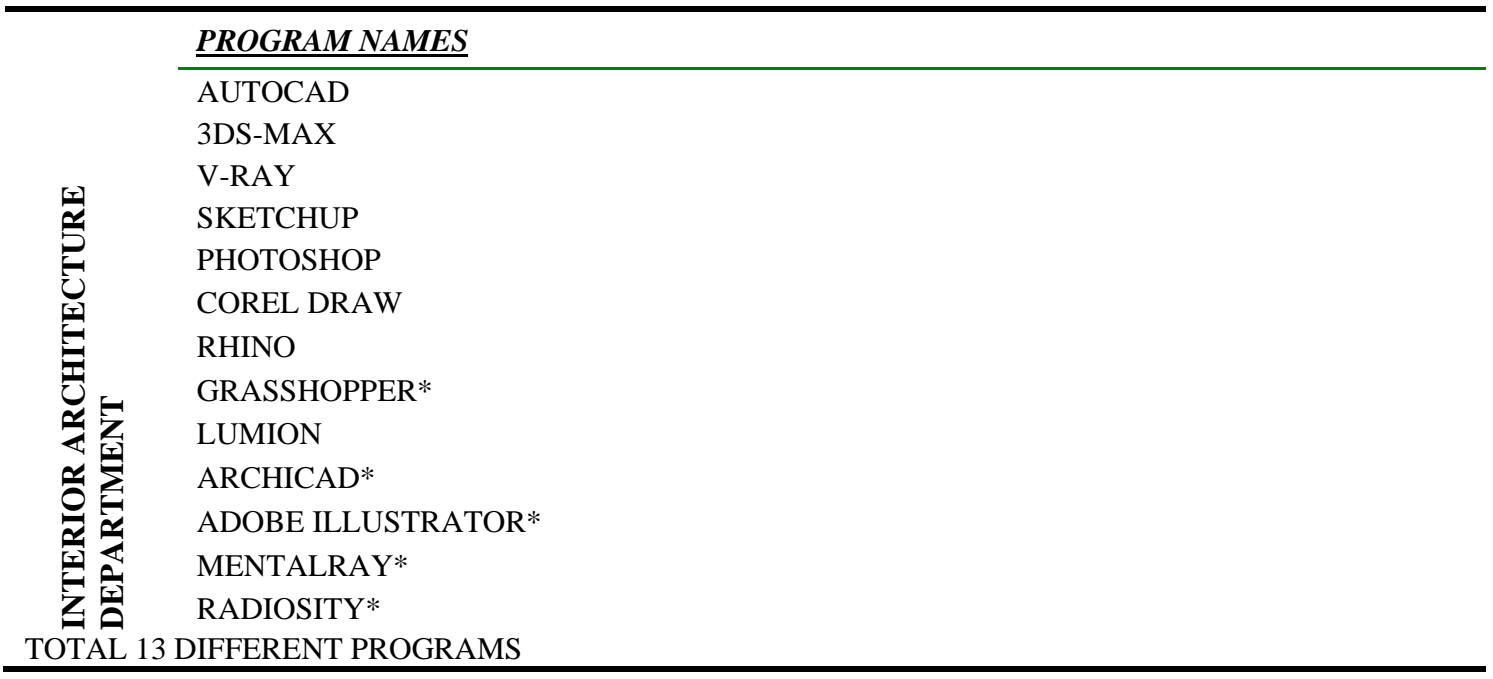

\section{Content of computer-aided drawing programs}

Within the scope of the study, the features of the computer-aided drawing programs taught in the departments with curriculum accessed were researched. The research findings are as follows:
AutoCAD program; Auto cad is a vector based drawing and modeling program. It is available for all operating systems and is owned by the CAD giant Autodesk. AutoCAD is among the leading programs for CAD (Bethany, 2017). It first began to be developed by the Autodesk company centered in America in 1980 and currently is the most commonly used CAD program. It was among the first vector-based 
drawing programs in the world. Drawings completed with AutoCAD are independent of resolution. Thus, the drawing can be easily enlarged or reduced without disrupting the image quality. Linked to the aim of the drawing, twodimensional or three-dimensional drawings may be easily made with the AutoCAD program. DWG is among the leading technical picture formats accepted around the world. This is the official file extension in the AutoCAD program. It was created using the English word 'drawing' without vowels. AutoCAD drawings are saved as files with DWG extension and can be easily opened on other computers. Again, due to DXF files developed by AutoCAD, drawings can be used interactively with other CAD programs (Teknikicerik, 2020).

3ds Max Program; 3ds Max is a vector based drawing and modeling program. The $3 \mathrm{D}$ studio max program was designed, developed and offered for use by the company Autodesk. 3D studio max is a modeling program that can be used for drawing, or more accurately 3D modeling. Easily used for many purposes like animation, modeling and 3 dimensional designs, the $3 \mathrm{D}$ studio max program is one of the newest innovations adapting to developing technologies. Due to the processing features and technology of graphics with advanced capability, the threedimensional models created with this program may be very realistic; in fact, models that cannot be distinguished from reality may be produced. With a very broad range, the $3 \mathrm{D}$ studio max program is frequently used in the film and animation sector, in addition to use for modeling the majority of characters in video games and environmental modeling in games. Used mostly in advertising, cinema and animation at present, the $3 \mathrm{D}$ studio max program has now become a necessity brought about by technology (Smartpro Computer Academy, 2020).

V-Ray Program; V Ray is a visualization execution and rendering engine. Produced by Chaos Group, the V-Ray program is a render engine used for 3D graphic implementation processes for all developers. It is used by all programmers as a ready render engine developed to produce more professional work in the visualization field.

It includes Irradiance Mapping, Light Cache and Photon Mapping for much more effective lighting of 3D scenes. These are applied in different combinations with the use of 'Direct Calculation' and 'Indirect Speech'. For the picture sampling process, one of the variations of the Schlick method of DMC is used. The selection rate is very high due to the broad range of choices for antialiasing processes. In addition to being effective, it offers photometric light support for consistent lighting solutions. The use of HDR support plays a role in effective production of sun depictions, sky depictions and similar features. When assessing elements within the scope of the technical features of V-Ray, the abundance of material and opportunity for effective use every time is important. With rich shadowing choices, the product is one of the best render motors which is very successful for fuzzy reflection methods. Additionally, the most important element providing field depth is undoubtedly camera support (Technology projects, 2020).

SKETCHUP Program; SketchUp is a vector modeling software. SketchUp is a software preferred by professionals as well as design students because of its accessible 3D modeling program. When a user simply draws the edges of the desired model, software fills the shapes to create 3D geometry (Übel, 2019). SketchUp was developed by @Last Software in 1999. In 2006, Google bought SketchUp after @Last Software created a plugin for Google Earth and caught the eye of the technology giant. In 2012, Trimble Navigation (now Trimble Inc.) bought SketchUp from Google and expanded the applications offering a new website containing plugins and extensions. SketchUp, previously known as "Google SketchUp" is 3D modeling software with comprehensive database that is easy to use, where models created by users can be uploaded. You can use it for model designs to assist with furniture construction, video game creation, 3D printing, interior design and any type of project you can imagine. SketchUp is an intuitive 3D modeling application allowing creation and editing of 2D and 3D models with a patented "push and pull" method. The push and pull tool ensures designers can pull 3D shapes to any flat surface. All you have to do is click on the object required and then begin to pull what you see wherever you like. SketchUp is a program used for a broad range of 3D modeling projects like architecture, interior design, landscape architecture and video game design (Sonsuzteknoloji, 2020)

Photoshop Program: Photoshop is a twodimensional rafter software program. It is a still image processing program. Photoshop is a configurable picture editor that can perform vector changes of previously created graphics and photographs. In other words, Photoshop assists in being able to edit previously existing pictures, more than creating new pictures. When 
performing this process, the most commonly used elements are cut, copy and delete. The aim of use allows contributions to many different areas. It can be used to renovate degraded, faded photographs, to give the desired colors to an existing photograph and to create a variety of entertainment factors. Generally. Photoshop is the pixel-based graphic and photograph processing software developed by AdobeSystems. Though AdobePhotoshop offers the opportunity to work with vector graphics, the main aspect of its power is its success for pixelbased images. In order to effectively use the Photoshop program, it is necessary to know what the program can do and the operation logic. If you know these, you will both motivate yourself in all learning stages and will grasp the true logic of the program (Atamedya, 2020).

Corel DRAW Program; Corel Draw is a 2D vector drawing program. It is generally used in the graphic field. Corel Corporation developed CorelDRAW software program as a vector graphic editor and first offered it to the market for Windows 2.x operating system in January 1989. Today, the software is still used by many people and CorelDRAW was designed by prioritizing the Windows operating system. The program contains tools to edit image collections and to capture screen images. Vector images have the advantage of convenient expansion or reduction without any loss of quality because the lengths of lines and curves and intersection points can be scaled in proportion to a grid. Generally, it is chosen by graphic designers (Berke Agency, 2020)

Rhinoceros Program; Rhino is a vector based Nurbs modeling program with $3 \mathrm{~d}$ software. Features include extremely fast 3D graphics, unlimited viewports, shaded, working views, perspective working views, named views, floating views, full-screen display, 3D stereo view modes, draw order support, two-point perspective, clipping planes, and one-to-one scale to view models at full size. (Rhinoceros, 2021)

Revit Program; Revit is a program that can carry the product with BIM software from the design phase to the implementation phase. Revit is a program designed by Autodesk, the producer of the famous AutoCAD program. Though currently known by the name "Autodesk Revit", the original software was developed by Charles River Software in 1997 and the name Revit was adopted from the Revit Technology Corporation in 2000. All rights to the program passed to the
Autodesk company in 2002. It was developed as information modeling software for construction engineers, architects, landscape architects, designers and contractors. As in the rest of the world, the interest in the Autodesk Revit program is increasing every day in Turkey. In this article, you can reach many details about the operation of this program, facilities offered and minimum system requirements (Smartpro Computer Academy, 2020).It allows the designer to design singular models and employs cloud computing to make sure all members of the design team have access to the information that they require. Revit BIM software retains data and adapts to the related changes. From one model, it is possible to extract other drawings. Any change in the 3D model will be reflected in $2 \mathrm{D}$ drawings or vice versa. There will be no need to go through drawings to ensure everything matches up, meaning it saves a lot of time. BIM software is suitable for architectural, mechanical, plumbing, electrical, electronics and communications projects, structural and construction coordination and documentation (Etiido, 2019).

Grasshopper Program; Grasshopher is a plugin that works within the Rhino program in parametric design. It is used for visual coding in organic models. This is a visual programing language and environment within the Rhinoceros 3D CAD application. The program was created by David Rutten working with Robert McNeel \& Associates. Programs are created by dragging components to a canvas. The outputs of these components are connected to the inputs of later components. Grasshopper is used to create productive algorithms, primarily like productive art. Most of the components of Grasshopper comprise 3D geometry. Programs may also include other algorithm types like numerical, textual, visual, audio and textural applications (Loomis, 2020). Among the advanced uses of Grasshopper are parametric modeling for structural engineering, parametric modeling for architecture and manufacturing, lighting performance analysis for environmentally friendly architecture and building energy consumption. After Grasshopper, the first version named Explicit History was published in September 2007. Grasshopper became part of the standard Rhino tool set in Rhino 6.0 and later versions (Fraguada, 2020).

Lumion Program; Lumion is a visualization execution and rendering engine. Lumion is the world's fastest 3D render software specially for architects. An architectural render solution, Lumion ensures architects can effectively 
transfer photo-realistic visuals and videos into CAD models (Softline, 2020). This program is an animation program that overcomes the animation deficiencies of the SketchUp program very well. Lumion is 3D rendering software made especially for architects and designers. If you have a 3D model of your design, Lumion can help you quickly bring it to life and show it in a richly detailed, captivating environment. No matter how you want to convey the beauty of your design, Lumion can help you do it yourself, quickly and without specialized training. (Lumion 10.5, 2020).

Twinmotion Program; Twinmotion is a visualization execution and rendering engine. Twinmotion, an imaginary world shared by developers and more than one hundred architecture firms around the world, was first designed by the Abvent company as a visualization and $3 \mathrm{D}$ virtual reality software for architecture, urban planning and landscape architecture. From May 2019, it was developed with the unrivaled power of the Unreal 4.0 motor by Epic Games. The Twinmotion program has the ability to create real-time render, material libraries and 3D presentations for designers, immobile images, videos and panoramas, to add animation to videos, add lighting and color specialization. It also offers additional effects (smoke, water, fire), a variety of filters, styles and preset presentation properties (İKİKALEM Architecture, 2020).

Archicad Program; Archicad is a vector drawing and modeling program. The 3D architecture software ArchiCAD was developed by Hungarian Company Graphisoft in 1982 for the Apple Macintosh. ArchiCAD was the first $\mathrm{CAD}$ product for the personal computer and is also the first implementation of BIM (Coorey, 2017) Since 1993, ArchiCAD has produced versions for the Windows operating system. ArchiCAD can provide real three-dimensional images for any desired perspective, frameworks, hidden background drawings, colored or photorealistic images with a single command without change the program or module. ArchiCAD is an architectural drawing and design program. You can use this program for full plans, sections and facades, architectural and implementation details, windows, doors, finishing plans, visual presentations, animations and virtual reality designs. Thus, instead of continuously repeatedly drawing these plans again and again, the whole project can be documented with ArchiCAD (Computer Training Center, 2020).
Adobe Illustrator Program; Adobe Illustrator is a $2 \mathrm{D}$ vector drawing program. It is generally used in the graphic field. Adobe Illustrator is a vector-based graphic design program developed by Adobe. Standing out with its advanced vector drawing capabilities, Illustrator is also one of the most used design programs by professionals in the world. The latest version of Illustrator CC2020 was offered to the market in 24 October 2019 and is the 24th generation of the product range. Adobe Illustrator was assessed as the best vector graphics editing program by $\mathrm{PC}$ magazine in 2018. Illustrator, with features ensuring advanced vector drawing facilities, is one of the design programs most commonly used by professionals around the world. As this program makes designs fully linked to vectors there is no disruption of the image no matter how large the dimensions of the work. The vector graphics created with Adobe Illustrator are independent of resolution. In other words, contrary to pixelbased design programs, they can be rescaled unlimited times without experiencing any loss of quality. In this context, unique vector drawings can be made with a variety of drawing tools contained within the program creating illustrations and typographies (Bidolubaski, 2021).

Mental Ray Program; Mental Ray is a visualization execution and rendering engine. Mental Ray is basically a rendering engine that can imitate the movement of light as in the real world, create raytraced reflection-refraction, and simulate light events such as Caustic and Global Illumination. This is a render software developed by the German Mental Images company. It is mostly used as a plugin for use by the 3D Studio Max program and is a preset in many $3 \mathrm{D}$ programs. Additionally, there is a version independent of program. The aim of development is realistic images. With Mental Ray it is possible to receive very realistic images and at the same time render with many computers (Şen, 2021).

Radiosity Program; Mental Ray is a visualization execution and rendering engine. Radiosity methods were first developed in the field of heat transfer engineering in the 1950s. Later in 1984 researchers from Cornell University and Hiroshima University developed a 3-dimenaional computer graphic application program specifically for this problem in creating computer graphics. Radiosity is a global lighting algorithm like irradiance monitoring or path tracking. It means that the light hitting a surface is not just from a direct lighting source, but also includes reflections of light from other surfaces. 
Radiosity is independent of perspective and this increases the relevant calculations; however, it makes it beneficial for all perspective viewpoints (Tamas, 2019).

\section{Discussion}

In line with the data obtained from the study findings, it has been revealed that the computeraided design courses given in the departments of interior architecture and interior architecture and environmental design differ greatly from each other. Located in topics queried in line with the objectives of the study "computer-aided drafting process taught in interior design training programs in Turkey and Northern Cyprus", a total of 11 different programs in interior architecture and environmental design department are taught. These are AutoCAD, 3dsMax, V-Ray, Sketchup, Photoshop, Corel Draw, Rhino, Revit, Lumion, Twinmotion programs. In the interior architecture department, a total of 14 different programs are taught. These are AutoCAD, 3ds-Max, V-Ray, Sketchup, Photoshop, Corel Draw, Rhino, Grasshopper, Lumion, Achicad, Adobe Ilustrator, Mentalray Radiosity.

Another subject discussed in the study is the software features of computer aided drawing programs taught in interior architecture departments. Software features are divided into 9 groups according to the data obtained within the scope of the research. These groups are: 1 . vector-based drawing and modeling program; 2 . visualization execution and rendering engine; 3 . vector modeling software; 4. two-dimensional rafter software program; 5 . 2D vector drawing program; 6. vector based Nurbs modeling program; 7. BIM software; 8. plugin that works within the Rhino; 9. visualization execution and rendering engine.

Finally, the aim is to reveal the similarities and differences between these programs. Programs offered in all universities have 9 different software features. Vector-based drawing and modeling programs are mostly taught. Autocad, Archicad and $3 \mathrm{ds}$ max programs are similar to each other as software. SketchUp is a different program that only works on modeling. It is different from another 2-dimensional visualization drawing programs that are taught, according to Photoshop, Corel and Illustrator. Photoshop rafter software feature, others are vectorial software. Programs such as V-ray, Mental Ray, Lumion, Twinmotion are similar render engine programs that are compatible with vector-based drawing programs.

Computer-aided drawing programs taught in the departments of interior architecture and interior architecture and environmental design at 63 universities should be reviewed and students should be fully prepared for business life when they graduate. Nowadays, the importance of computer-aided drawing comes to the fore once again in line with the employer's request. Customer designs are no longer satisfied with seeing 2D. Customers want to imagine places with a real photo image. However, it is desired that students graduate from universities with the same or similar computer skills. Vectorial drawing and modeling programs should be taught in universities at an early stage. In order to present them, visual formatting programs with photo-realistic imaging and 2D rafter or vectorial software features should be provided together.

\section{Conclusion}

As a result of the study, curricula from 31 out of a total of 32 interior architecture departments were reached. Curricula from 28 out of a total of 31 interior architecture departments were reached.

According to screening in March 2020, all universities in Turkey and TRNC providing education in interior architecture and interior architecture and environmental design linked to YÖK, apart from one, provide education in computer-aided drawing programs.

Differences were revealed in the computer-aided drawing lessons in the interior architecture and environmental design and interior architecture departments linked to YÖK.

According to the data obtained, both departments appear to include computer-aided drawing lessons most intensely in the 2nd year on the mandatory curriculum. When the semester rates are examined, these lessons are mainly included in the 3rd and 4th semesters.

According to information obtained as a result of literature research, in 1992 computer-aided drawing lessons were observed to be given in the 3rd and 4th semesters, similar to today.

Computer lessons given over the total of 4 years in the departments comprise a total of 149 lessons. There were 83 lessons in the interior 
architecture and environmental design and 66 lessons in the interior architecture department.

A common lesson in all universities was AutoCAD and AutoCAD alone is not considered sufficient in the present day. Within the framework of curricula in education, 2- and 3dimensional computer-aided drawing lessons are given in order and it is very important that graduating students can use the necessary programs competently before and after graduation.

The study was completed to determine the variety of computer-aided drawing programs taught in universities and content features.

In line with this, information was reached that there were similarities and differences in the software features of computer-aided drawing programs used in programs in interior architecture and interior architecture and environmental design departments linked to YÖK.

Some universities only teach 2-dimensional computer programs, while some universities appear to teach 2-dimensional, 3-dimensional modeling programs and the supportive lighting and camera setting photorealistic rendering programs supporting these programs on the curriculum.

Students learning the software required by the age and using these systems in the most capable way will meet expectations on the market after education.

Finally, it is understood from the research that the computer-aided drawing programs taught during interior architecture education are current and appropriate for the present day. Though different computer-aided drawing programs are taught, these programs have similar forms of use to each other, as understood when the software features are investigated. It is thought necessary that our universities providing education in interior architecture and interior architecture and environmental design should add new programs to the curriculum during education and ensure interior architecture students are prepared for this technology and the present day.

\section{Bibliographic References}

Ataç, I. (1992). Architecture with Machines, Principles and Examples of CAAD Education at the TU Munich, ECAADE 1991 International Conference Proceedings, Munich, Proc.:3
Atamedya (2020). Photoshop. https://ata.com.tr/blog-detay/photoshop-nedirphotoshop-nasil-kullanilir-85, (Date of access: 15.10.2020)

Aydın, E.D. (2004). Contemporary Approaches to Basic Design (author's own publication), 259-260.

Baker, R. (1993). Design The Future: the computer in architecture and design. Londres: Thames \& Hudson, 21.

Bardak, S., (2007). The Place and Problems of Computer Aided Design in Interior Architecture Education (Master's Thesis), Mimar Sinan Fine Arts University, Turkey. 190s.

Berke Agency (2020). Corel Draw. https://berkeajans.com/coreldraw-nedir-nasilkullanilir.html, (Date of access: 16.10.2020) Bethany, (2017). Which Architecture Software Should I Use? Scan2CAD. Available: https://www.scan2cad.com/architecture/architec ture-software/

Bidolubaski (2021). Adobe Illustrator. https://www.bidolubaski.com/blog/adobeillustrator-nedir-ve-neden-kullanilir, (Date of access: 01.03.2021)

Computer Training Center (2020). Archicad. https://blog.bilisimegitim.com/archicad-nedir/,

(Date of access: 18.10.2020)

Coorey, B. (2017). BIM software, the advantages and disadvantages of Revit. Linkedin. Retrieved from

https://www.linkedin.com/pulse/advantages-

disadvantages-revit-dr-benjamin-coorey

Denerel, S.B (2011). A Research on the Effects of Traditional and Computer Aided Drawing Tools on Landscape Architecture Design Process (Doctorate Thesis) Ege University, Turkey. 38-40.

Denerel, S., \& Birişçi, T. (2019). A Research on Landscape Architecture Student Use of Traditional and Computer-Aided Drawing Tools. Amazonia Investiga, 8(24), pp. 373-385 https://amazoniainvestiga.info/index.php/amazo nia/article/view/979

Eczacibas1 Art Encyclopedia (1997). İstanbul: Yem Yayın, Cilt:, 244-245

Etiido, (2019), How Much Does Vectorworks Cost? Pricing Explained. Scan2CAD https://www.scan2cad.com/cad/vectorworkspricing/

Fraguada, L. (2020). Grasshopper Algoritmic Modelling for Rhino. https://www.grasshopper3d.com/group/ghowl, (Date of access: 01.03.2021)

İKIKKALEM Architecture. (2020). Twinmotion, https://www.ikikalem.com/twinmotion/, (Date of access: 18.10 .2020$)$

Ketizmen, G. (2002). Examination of the methodological and spatial effects in the Shaping 
of the Architectural Design Studio (Master's Thesis) Anadolu University, Turkey. 187s.

Loomis, M. (January 10, 2011). Rhino Grasshopper VS Generative Components (Blog). Designplaygrounds.

Lumion (2020). Lumion 10.5, https://lumion.com/product.html, (Date of access: 18.10.2020)

Martens, B., \& Peter, H. (2004). ArchiCAD. New York: Springer Science \& Business Media. Mitton, M. (2003). Interior Design Visual Presentation: A Guide to Graphics, Models, and Presentation Techniques. New York: John Wiley \& Sons Inc. 2-44.

Onur, A. Z., \& Nouban, F. (2019). Software in the Architectural Presentation And Design Of Buildings: State-Of-The-Art. International Journal of Innovative Technology and Exploring Engineering (IJITEE) [Online], 8(10).

Rhinoceros (2021). Features. https://www.rhino3d.com/features/, (Date of access: 01.03.2021)

Scheer, D. R. (2014). The Death of Drawing: Architecture in the Age of Simulation. First Edition. New York: Routledge.

Şen. M. (2021). Mental Ray. Tr3d https://www.tr3d.com/dersler/ders/6b/ (Date of access: 01.03.2021)

Smartpro Computer Academy. (2020). 3ds Max. https://smartpro.com.tr/egitimlerimiz/3d-studiomax-egitimi-kursu/ (Date of access: 01.03.2021) Smartpro Computer Academy (2020). Revit. https://smartpro.com.tr/revit-nedir/, (Date of access: 16.10 .2020$)$

Softline. (2020). Lumion. https://softlineyazilim.com.tr/cozumler/grafik- dizayn/lumion\#: :text=Lumion

$\% 2 \mathrm{C} \% 20$ mimarlara\%20\%C3\%B6zel\%2C\%20d

$\% \mathrm{C} 3 \% \mathrm{BCnyan} \% \mathrm{C} 4 \% \mathrm{~B} 1 \mathrm{n} \% 20 \mathrm{en}$,

ve\%20sanatsal

$\%$ 20dokunu\%C5\%9Flarla\%20g\%C3\%B6rseller e $\% 20 \mathrm{~d} \% \mathrm{C} 3 \%$ B6n\%C3\%BC

$\% \mathrm{C} 5 \% 9 \mathrm{Ft} \% \mathrm{C} 3 \% \mathrm{BCrebilirsiniz,}$, Date of access: 16.10.2020)

Sonsuzteknoloji. (2020). SketchUP.

https://www.sonsuzteknoloji.com/?s=skech+up \&pum_form_popup_id=23448 (Date of access: 01.04.2021)

Tamas, (2019). Progressive radiosity tutorial with OpenGL. GitHub. https://github.com/TamasKormendi/openglradiosity-tutorial, (Date of access: 18.10.2020)

Technology projects (2020). V-Ray, https://teknolojiprojeleri.com/programlar/v-ray, (Date of access: 15.10.2020)

Teknikicerik (2020).

AutoCAD. http://www.teknikicerik.com/autocadnedir.html, (Date of access: 12.10.2020) The New School (2019). "Parsons History", Kasim.

https://www.newschool.edu/parsons/history/ Utkutuğ, G., (2000). Computer-Based Technologies and Architecture, Science and Technology. Tübitak Publications, November issue free supplement, 4.

Übel, V. M. (2019). Best 3D Architecture / BIM Software (Many are Free) all3dp. Retrieved from https://all3dp.com/1/best-3d-architecturesoftware/\#microstation (Date of access: 01.03.2021) 